\title{
The home range of a recently established group of Southern ground-hornbill (Bucorvus leadbeateri) in the Limpopo Valley, South Africa
}

\begin{tabular}{|c|c|}
\hline \multicolumn{2}{|c|}{$\begin{array}{l}\text { Authors: } \\
\text { Nicholas Theron }{ }^{1,2} \\
\text { Raymond Jansen }^{3} \\
\text { Paul Grobler } \\
\text { Antoinette Kotze } \\
\text { 1,4 }\end{array}$} \\
\hline \multicolumn{2}{|c|}{$\begin{array}{l}\text { Affiliations: } \\
{ }^{1} \text { Department of Genetics, } \\
\text { University of the Free State, } \\
\text { South Africa }\end{array}$} \\
\hline \multicolumn{2}{|c|}{$\begin{array}{l}{ }^{2} \text { Mabula Ground Hornbill } \\
\text { Research and Conservation } \\
\text { Project, Bela-Bela, } \\
\text { South Africa }\end{array}$} \\
\hline \multicolumn{2}{|c|}{$\begin{array}{l}{ }^{3} \text { Department of } \\
\text { Environmental, Water and } \\
\text { Earth Sciences, Tshwane } \\
\text { University of Technology, } \\
\text { South Africa }\end{array}$} \\
\hline \multicolumn{2}{|c|}{$\begin{array}{l}{ }^{4} \text { National Zoological Gardens } \\
\text { of South Africa, Pretoria, } \\
\text { South Africa }\end{array}$} \\
\hline \multicolumn{2}{|c|}{$\begin{array}{l}\text { Correspondence to: } \\
\text { Nicholas Theron }\end{array}$} \\
\hline \multicolumn{2}{|c|}{$\begin{array}{l}\text { Email: } \\
\text { nicktheron@live.co.za }\end{array}$} \\
\hline \multicolumn{2}{|c|}{$\begin{array}{l}\text { Postal address: } \\
\text { PO Box 864, Underberg 3257, } \\
\text { South Africa }\end{array}$} \\
\hline \multicolumn{2}{|c|}{$\begin{array}{l}\text { Dates: } \\
\text { Received: } 09 \text { Jan. } 2013 \\
\text { Accepted: } 08 \text { Aug. } 2013 \\
\text { Published: } 11 \text { Oct. } 2013\end{array}$} \\
\hline \multicolumn{2}{|c|}{$\begin{array}{l}\text { How to cite this article: } \\
\text { Theron, N., Jansen, R., } \\
\text { Grobler, P. \& Kotze, A., } \\
\text { 2013, 'The home range of a } \\
\text { recently established group } \\
\text { of Southern ground-hornbill } \\
\text { (Bucorvus leadbeateri) in the } \\
\text { Limpopo Valley, South Africa', } \\
\text { Koedoe 55(1), Art. \#1135, } \\
8 \text { pages. http://dx.doi.org/ } \\
10.4102 / \text { koedoe.v55i1.1135 }\end{array}$} \\
\hline \multirow{2}{*}{ Read online: } & \\
\hline & $\begin{array}{l}\text { Scan this QR } \\
\text { code with your } \\
\text { smart phone or } \\
\text { mobile device } \\
\text { to read online. }\end{array}$ \\
\hline
\end{tabular}

Authors:

Nicholas Theron

Affiliations: University of the Free State, Project, Bela-Bela

${ }^{3}$ Department of

Environmental, Water and Earth Sciences, Tshwane University of Technology, uth Africa

of South Africa, Pretoria, South Africa

\section{Correspondence to:}

Email:

nicktheron@live.co.za

Postal address:

PO Box 864, Underberg 3257,

Dates:

Received: 09 Jan. 2013

Accepted: 08 Aug. 2013

How to cite this article: Theron, N., Jansen, R. Grobler, P. \& Kotze, A. 2013, The home range of a of Southern ground-hornbil (Bucorvus leadbeateri) in the Limpopo Valley, South Africa', Koedoe 55(1), Art. \#1135, 8 pages. http://dx.doi.org/ 10.4102/koedoe.v55i1.1135
Little is known about Southern ground-hornbill (SGH) population ecology outside of large, formally protected areas where the largest declines in numbers have been recorded. The SGH has started re-colonising, establishing group territories and breeding successfully in the Limpopo Valley on the northern border of South Africa, following localised extinction from the 1950s to the 1970s. A group of SGH was monitored over a period of 14 months by means of radio telemetry across privately owned land in order to investigate their seasonal habitat movements in this semi-arid, predominantly livestock-based environment. We also investigated seasonal fluctuations in invertebrate prevalence, as an indication of food availability and its influence on seasonal SGH group movements and foraging activity patterns. There was a clear increase in food availability during the summer rainfall period allowing the group to forage over a wider area, whilst winter foraging remained localised within their range. Kernel home range analysis indicated a marked difference in size between the summer (13 409 ha) and winter (5280 ha) home ranges, with an overall home range of 19372 ha, which is approximately double that of home ranges recorded that fall within formally and informally protected reserves. In this article, we proposed that food availability is the driving force for home range size and seasonal activity patterns in a semi-arid livestock-ranching habitat.

Conservation implications: The Limpopo Valley SGH population is one of the most significant outside protected areas in South Africa. This population is especially vulnerable to threats such as poisoning, persecution for window breaking and drought, as shown by their near extirpation from the area. Conservation efforts need to focus on awareness amongst local farmers, provision of artificial nests and continued monitoring of groups.

\section{Introduction}

The Southern ground-hornbill (SGH) (Bucorvus leadbeateri) is the largest hornbill in the world and the largest cooperatively breeding bird species (Kemp \& Kemp 1980). It is a territorial, sedentary species and occurs in groups averaging 3-4 individuals consisting of an alpha pair and a mixture of juveniles and adult helpers (Kemp \& Kemp 1980; Knight 1990). The species is officially listed as vulnerable in South Africa (Kemp 2000), whilst a recent review of the International Union for Conservation of Nature (IUCN) global status has precipitated a change in the species' status from least concern to vulnerable by BirdLife International (2010). The South African population is estimated at between 1500 and 2000 individuals, with almost half of this population (600-700 individuals) found in the Kruger National Park (KNP) (Kemp 2005). The reduction in numbers has primarily been associated with habitat degradation, persecution for window breaking, secondary poisoning and the loss of suitable large trees for nesting. In order to reverse these negative population trends, a critical component of the species' conservation strategy will be to understand what constitutes ideal SGH habitat. Suitability of habitat can be seen to contribute to the overall fitness and survival of an individual (Block \& Brennan 1993) and the resources and conditions necessary to allow an organism to survive, reproduce and persist (Hall, Krausman \& Morrison 1997).

According to Kemp (1988), nesting sites are the primary resource associated with SGH territories, whilst food resources are secondary. Data from ground and aerial counts in the KNP spanning 20 years indicated that there exists no relationship between the frequency groups were encountered and group size with the distribution of rainfall, geology, geomorphology, drainage lines, soil types, vegetation types or vegetation structure (Kemp, Joubert \& Kemp 1989). The importance of food resources to the species in African savannas is shown by the influence it has on SGH behaviour. During periods of lowest food abundance in winter, SGH adapt their behaviour by concentrating in areas around waterholes that have higher densities of ungulates and where food

Copyright: @ 2013. The Authors. Licensee: AOSIS OpenJournals. This work is licensed under the Creative Commons Attribution License. 
abundance will be higher (Kemp et al. 1989). Furthermore, observations indicate SGH dig more during the drier months of the year when surface prey is less abundant, often in and around piles of elephant dung (Kemp 1995) and in rhino middens. The onset of breeding is also restricted to the summer months (October-March) and is triggered by the start of the summer rains. It is this summer rainfall that is believed to be the proximate factor influencing the seasonal availability of food for the species, primarily invertebrates (Kemp 1976; Kemp \& Kemp 1991) which form an important component of SGH diet during the wetter summer months (Kemp \& Kemp 1978; Knight 1990). In South Africa, densities of one group per $100 \mathrm{~km}^{2}$ are recorded in the KNP (Kemp \& Kemp 1980), KwaZulu-Natal midlands (Knight 1990) and the Eastern Cape (Vernon 1984), whilst observations indicate densities of approximately one group per $20 \mathrm{~km}^{2}$ in the Mana pools region of Zimbabwe (Kemp 2005) and the Masai Mara in Kenya (N. Theron, pers. obs.).

Southern ground-hornbills disappeared from the Limpopo Valley during the 1950s-1970s (pers. comm. land owners), likely the result of extreme drought conditions and overgrazing aggravated by threats such as poisoning, electrocutions and persecution for window breaking. Re-colonisation since the early 1990s has subsequently occurred in the region with the establishment of successful breeding groups. Only 10 groups are known north of the Soutpansberg Mountains, between the Platjan Border Post and the towns of Alldays and Musina, with an estimated density of approximately one group per $600 \mathrm{~km}^{2}$ (Theron et al. 2013). One group, which is the focus of this study, has been present in the area since the mid-1990s and has bred in an Adansonia digitata (baobab tree) at least twice from the summer of 2008 until the summer of 2011 (N. Theron, pers. obs.).
Home range, habitat use, foraging behaviour and breeding success of SGH outside formally protected areas has not been investigated. Furthermore, behavioural studies on re-emerging SGH populations have yet to be undertaken. This is especially important in terms of developing a management plan for the conservation of this threatened species particularly for those areas they historically occupied. Moreover, quantitative seasonal data on the general availability of prey resources that include invertebrate abundance and the influences this has on foraging behaviour patterns of SGH, especially during the winter months (March-August), are still poorly understood. This study is a first attempt at quantifying the seasonal movement patterns of a group of SGH within a predominantly agricultural landscape outside of a protected area. Furthermore, this study aims to investigate the seasonal availability of invertebrates in relation to rainfall, temperature and changes in vegetation cover and the possible consequence this may have on the habitat utilisation, movement and seasonal home range size of a group of SGH in the Limpopo Valley.

\section{Research method and design Study area}

The study was undertaken from July 2008 to October 2009 in the Limpopo Valley, a semi-arid landscape that forms part of the savanna biome at an altitude ranging between 300 m.a.s.l. and 1000 m.a.s.l. (Mucina \& Rutherford 2006) on the northern border of South Africa with Zimbabwe (Figure 1) at the northwestern extent of the SGH's range in South Africa. The main vegetation types, classified by Mucina and Rutherford (2006), include Musina Mopane Bushveld making up the majority of the plains and Limpopo Ridge Bushveld covering the hills

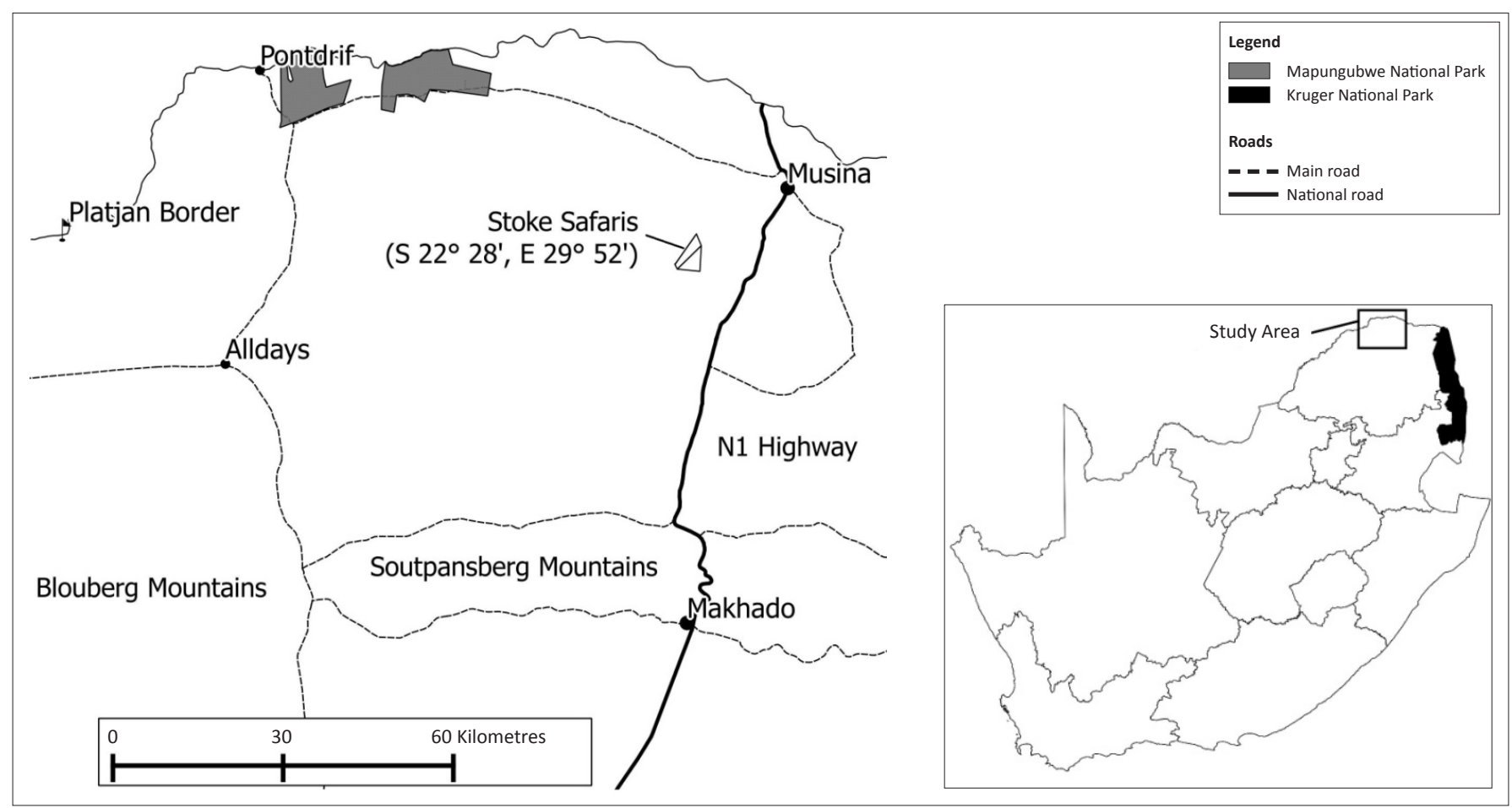

FIGURE 1: Map of the study area in South Africa (inset) with a detailed map of the Limpopo Valley and the location of Stoke Safaris where invertebrate and vegetation data were collected. 
and ridges scattered throughout the area. Colophospermum mopane (mopani) trees, broad-leaved deciduous species such as $A$. digitata, Terminalia prunioides (Lowveld Cluster Leaf) and various species of Commiphora dominate the area $(\mathrm{N}$. Theron, pers. obs.). The Limpopo Valley is a low rainfall area, with a yearly average of $341.6 \mathrm{~mm}$ (Jordaan et al. 2004) and a mean monthly temperature ranging between $15.5^{\circ} \mathrm{C}$ and $29.9^{\circ} \mathrm{C}$. Rainfall is seasonal and sporadic, with $79.7 \%$ of the total precipitation occurring in summer (data from 1980-2009 supplied on request by the South African Weather Service). Commercial cattle and game ranching dominate the landuse, with an estimated 3.0\% of Musina Mopane Bushveld and $1.0 \%$ of Limpopo Ridge Bushveld transformed mainly for agriculture (Mucina \& Rutherford 2006). The area is further characterised by low average rainfall, shallow nutrient poor and severely eroded soils with low moisture retention (Jordaan et al. 2004).

\section{Study sites}

Four study sites within the group's territory were randomly chosen on the Stokes farm ( $\left.242 \mathrm{MS} ; 22^{\circ} 28^{\prime} \mathrm{S}, 2^{\circ} 52^{\prime} \mathrm{E}\right)$ to collect vegetation and invertebrate data from October 2008 to September 2009. These study sites were targeted because of the constant presence of SGH on the farm over a number of months. Sites 2 and 3 were historically grazed by cattle and are now stocked with indigenous game species. Site 1 is currently a breeding camp for Nyala (Tragelaphus angasii) and Sable antelope (Hippotragus niger). Site 4 is old agricultural land that was abandoned more than 15 years ago.

\section{Vegetation sampling}

A visual estimate of cover to describe temporal changes in vegetation was conducted monthly at 10 geo-referenced points per site. Canopy cover of grass species formed the focus of this estimate by using a $1 \mathrm{~m}^{2}$ metal quadrant at each point and the percentage grass cover estimated according to the following categories: < 10\%, 10\% - 25\%, 25\% - 50\%, $50 \%-75 \%$ and $75 \%-100 \%$. Each category was allocated a score, with one being the lowest and five the highest, to compile a monthly score ranging between 10 and 50. The overall condition score for each replicate was ascribed by those developed for this habitat by Jordaan et al. (2004), where three categories were described depending on seasonal precipitation levels, namely: extremely bad (bare soil and forbs dominate), bad (annual grasses such as Aristida spp. dominate) and good (annual grasses such as Aristida spp. and perennial grasses such as Eragrostis lehmanniana dominate).

\section{Invertebrate sampling}

Both pitfall and sweep net methods were employed to target invertebrates that would mostly be encountered by a SGHs mode of foraging behaviour. Pitfall samples would include species that are mainly ground-dwelling, whilst sweep netting would sample invertebrates occurring predominantly on surface vegetation (Standen 2000). Pitfall traps and sweep netting methods were employed monthly from October 2008 to September 2009 to determine seasonal availability at the same geo-referenced site the vegetation was sampled. At each site, 13 pitfall traps were set out using the nested cross array method (Perner \& Schueler 2004). Plastic tubes with a $10 \mathrm{~cm}$ diameter and $15 \mathrm{~cm}$ in length were buried flush with the soil surface and cups dropped into each and filled with propylene glycol up to $3 \mathrm{~cm}$ deep. Propylene glycol is non-toxic and safe for animals that may feed on invertebrates caught in traps. Pitfalls were left out for a sampling period of 4 days each month. Pitfalls disturbed by animals were not included in the analysis as selected invertebrates may have been removed. Invertebrates were washed and stored in polytop vials with a $75 \%$ ethanol solution for later identification up to order level. Sweep netting was performed monthly by walking the same geo-referenced $200 \mathrm{~m}$ transect at each of the four sites within the same week pitfalls were sampled. A $45-\mathrm{cm}$ diameter net was used to take sweep net samples where 200 sweeps were performed per line transect (one sweep for each step taken) before $10 \mathrm{am}$. All invertebrates were identified up to the level of order, counted and measured volumetrically using the volumetric water displacement method (Jansen \& Crowe 2006).

\section{Home range analysis}

A group of five SGH consisting of an alpha male, alpha female, one sub-adult male and female and one juvenile was captured by luring them into a netting trap with a fibreglass SGH model and a vocal territorial recording. A Holohil ${ }^{\circledR}$ tail transmitter was fitted onto the main tail deck-feather of the alpha female. After a 30-day settling period, the group was tracked using a handheld yagi antennae and an $\mathrm{AOR}^{\circledR}$ receiver. Locality data were collected every 3-4 h where possible, including roost sites, 5 days a month from August 2008 to September 2009. Nest sites were identified in order to assess their possible influence on the movement of groups in the landscape. GPS readings were recorded using a Garmin ${ }^{\circledR}$ GPS. Other factors such as the influence of human structures (buildings, roads and highways) on the group's movements were also observed and recorded.

\section{Data analysis}

Ranges VII software (South, Kenward \& Walls 2008) was used to analyse home range data where the harmonic mean and kernel home range calculations were used in estimating seasonal home range size. Harmonic mean home range estimates are highly sensitive to outlying observations and thus force the inclusion of many grid points. As such, the outcome of the home range size is an overestimate of true size, whereas kernel estimators are well defined and tractable (Seaman \& Powell 1996) and are presented in this study. Furthermore, GPS co-ordinates were loaded into QGIS 1.8.0 Lisboa (Open Source Geospatial Foundation Project) and overlayed on 1:10 000 high resolution orthophotos and spatial layers representing rivers, roads and vegetation types to further note if any associations exists with group movements and structural habitat features.

Statistical data analysis was undertaken using the software program STATISTICA (2009). Kruskal-Wallis one way analysis of variance (ANOVA) was used to test for any variations 
between sites with regards to invertebrate prevalence and vegetation cover. A correlation analyses was performed (Spearman's) to determine if there exists any association between invertebrate numbers and grass cover.

Correlations were performed against invertebrate data and relevant meteorological data (rainfall as well as maximum and minimum temperatures) where $p<0.05$ (95\%) denotes significance. A two tailed $t$-test was further employed to test whether there was any significant difference between invertebrate sampling methods.

\section{Results}

\section{Vegetation}

Monthly estimates of cover were very similar across all four sites (ANOVA: $\mathrm{KW}=2.12, d f=3, p=0.5470$ ) and the average overall monthly score for all sites was very low at 17.7 , representing an average cover of between $10.0 \%$ and $25.0 \%$. The veld condition using the Jordaan et al. (2004) criteria ranks each site as extremely bad throughout the study period. Graphical representation of grass cover and rainfall revealed the close relationship between precipitation and the response of vegetation growth (Figure 2). Grass growth was only stimulated following the December-January rains $(272.6 \mathrm{~mm})$, resulting in the highest grass cover scores during February. The total annual rainfall during the study was $40 \%$ above average at $477.7 \mathrm{~mm}$, of which $460 \mathrm{~mm}(94.6 \%)$ fell during summer (November-March).

\section{Invertebrates}

The two sampling methods differed significantly with the pitfall traps being the most successful $(t=6.25, d f=21$, $p<0.001)$. Sweep netting yielded a total of 1193 individuals in comparison to the pitfalls with a total of 18272 (Table 1). The pitfall data showed positive correlations between the number of invertebrates with both mean monthly maximum temperatures $\left(r^{2}=0.531, p<0.05\right)$ and minimum temperatures $\left(r^{2}=0.612, p<0.05\right)$ and the volume of invertebrates with mean monthly rainfall $\left(r^{2}=0.563, p<0.05\right)$. No associations were found between meteorological variables and sweep net data. As such, sweep net data proved unreliable and pitfall data seemed a more appropriate method of collecting invertebrates in this very arid environment. All statistical procedures made use of pitfall invertebrate data and sweep net data was not used. Invertebrate numbers and volume

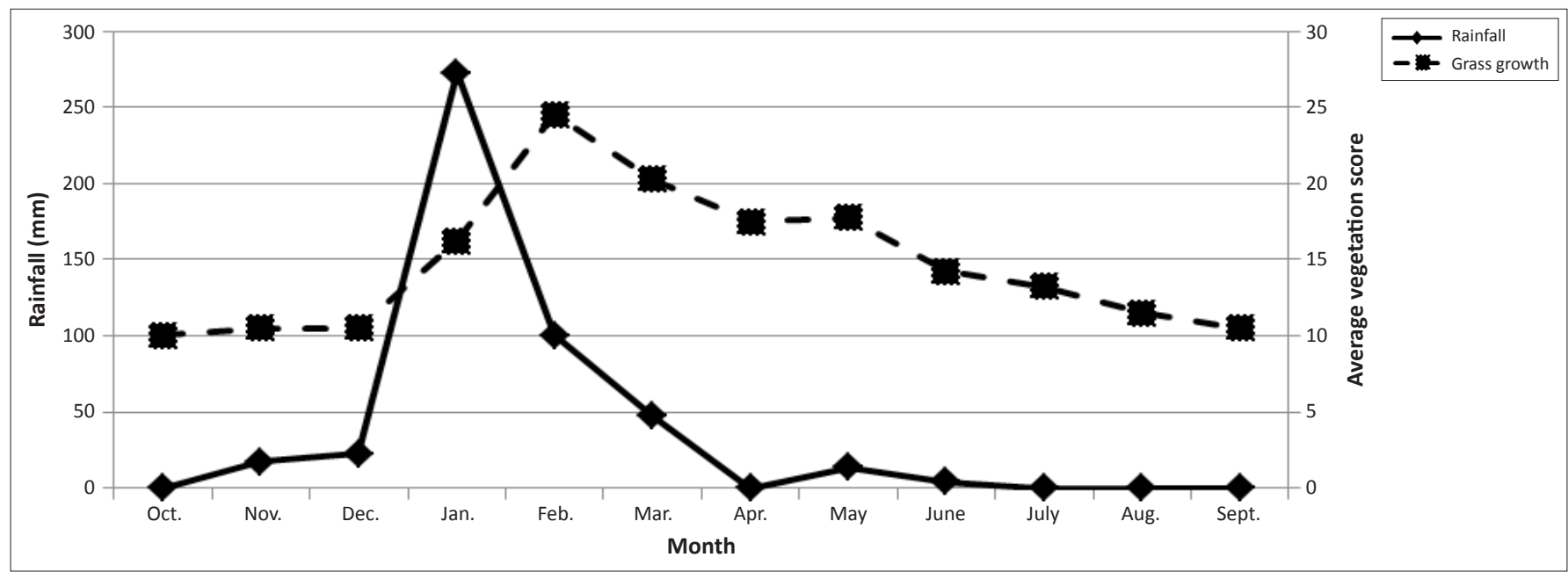

FIGURE 2: Seasonal comparison of rainfall and grass cover scores.

TABLE 1: Total numbers and volume of invertebrates captured from October 2008 to September 2009 using two sampling methods. No invertebrates were captured using sweep nets during the months of October and December.

\begin{tabular}{|c|c|c|c|c|c|c|c|c|}
\hline \multirow[t]{3}{*}{ Month } & \multicolumn{4}{|c|}{ Sweep nets } & \multicolumn{4}{|c|}{ Pitfalls } \\
\hline & \multicolumn{2}{|c|}{ Invertebrate numbers } & \multicolumn{2}{|c|}{ Invertebrate volume } & \multicolumn{2}{|c|}{ Invertebrate numbers } & \multicolumn{2}{|c|}{ Invertebrate volume } \\
\hline & $n$ & $\%$ & $\mathrm{~mL}$ & $\%$ & $n$ & $\%$ & $\mathrm{~mL}$ & $\%$ \\
\hline October & 0 & 0.00 & 0.00 & 0.00 & 2554 & 13.98 & 44.66 & 2.56 \\
\hline November & 81 & 6.79 & 1.38 & 0.82 & 1174 & 6.43 & 250.53 & 14.37 \\
\hline December & 0 & 0.00 & 0.00 & 0.00 & 1833 & 10.03 & 44.31 & 2.54 \\
\hline January & 194 & 16.26 & 21.99 & 13.01 & 2078 & 11.37 & 383.45 & 21.99 \\
\hline February & 177 & 14.84 & 16.32 & 9.66 & 2794 & 15.29 & 256.97 & 14.73 \\
\hline March & 211 & 17.69 & 28.96 & 17.14 & 2037 & 11.15 & 339.98 & 19.49 \\
\hline April & 207 & 17.35 & 36.55 & 21.63 & 1041 & 5.70 & 126.42 & 7.25 \\
\hline May & 64 & 5.36 & 2.69 & 1.59 & 1028 & 5.63 & 142.77 & 8.19 \\
\hline June & 99 & 8.30 & 28.29 & 16.74 & 773 & 4.23 & 50.16 & 2.88 \\
\hline July & 46 & 3.86 & 12.95 & 7.66 & 462 & 2.53 & 26.40 & 1.51 \\
\hline August & 66 & 5.53 & 18.15 & 10.74 & 846 & 4.63 & 27.99 & 1.60 \\
\hline September & 48 & 4.02 & 1.34 & 0.79 & 1652 & 9.04 & 50.66 & 2.90 \\
\hline
\end{tabular}

n, number of invertebrates. 
peaked during summer (November-April) and were lowest in mid-winter (May-July; Table 1). There were no significant differences between sites with regards to the number or volume of invertebrates sampled using pitfall traps (ANOVA: $\mathrm{KW}=0.539, d f=3, p=0.910)$. Furthermore, no association was found between invertebrate numbers (prevalence) and relative grass cover (Spearman $r=0.07, p=0.834$ ).

Differences between the compositions of orders between the two sampling methods were apparent (Figures 3a-3d). Coleopterans dominated pitfall sampling and made up $62 \%$ of the numbers and $76 \%$ of the total volume. Orthopterans were the most abundant order sampled with sweep nets for both numbers and volume, representing $62 \%$ and $76 \%$ respectively. Orthoptera were the second-most abundant order in terms of pitfall volume, making up $6 \%$ of the total volume. Other notable differences in the most dominant orders collected for the two sampling methods were Hemiptera, which represent a significant proportion of the invertebrates captured by sweep netting but not in pitfall traps for both numbers and volume, whilst the converse was true for the order of Hymenoptera; strongly represented in the pitfalls but not the sweep net sample set.

\section{Home range size and habitat utilisation}

A total of 201 fixes were recorded. The territory size of the group varied between 19372 ha and 22731 ha by the kernel and harmonic mean home range analysis, respectively. The results of the kernel home range indicated a summer (September-February) and winter (March-August) size of 13409 ha (Figure 4a) and 5280 ha (Figure 4b), respectively. Although the group would generally avoid areas with human activity, roads and highways did not seem to restrict movement of the group as these were easily traversed, often regularly. A total of three baobab trees with suitable nesting cavities were recorded, with the female spending at least one day in each nest. The group did not breed during the study period and the female was never observed in the primary nest tree which was used historically by the group. The group subsequently bred in this nest during the 2009-2010 season. Finally, this study highlighted the limitations of using radio telemetry to follow SGH groups in this challenging environment where farms are all privately owned and acquiring permission to access a property can be difficult. Ideally, a number of emerging SGH groups should be fitted with satellite transmitters to suitably quantify home range and habitat use in this environment.

\section{Ethical considerations}

The project was approved by the ethics and scientific committee of the National Zoological Gardens of South Africa. All relevant permits and permission from landowners were acquired before capture of the SGH group and during fieldwork.

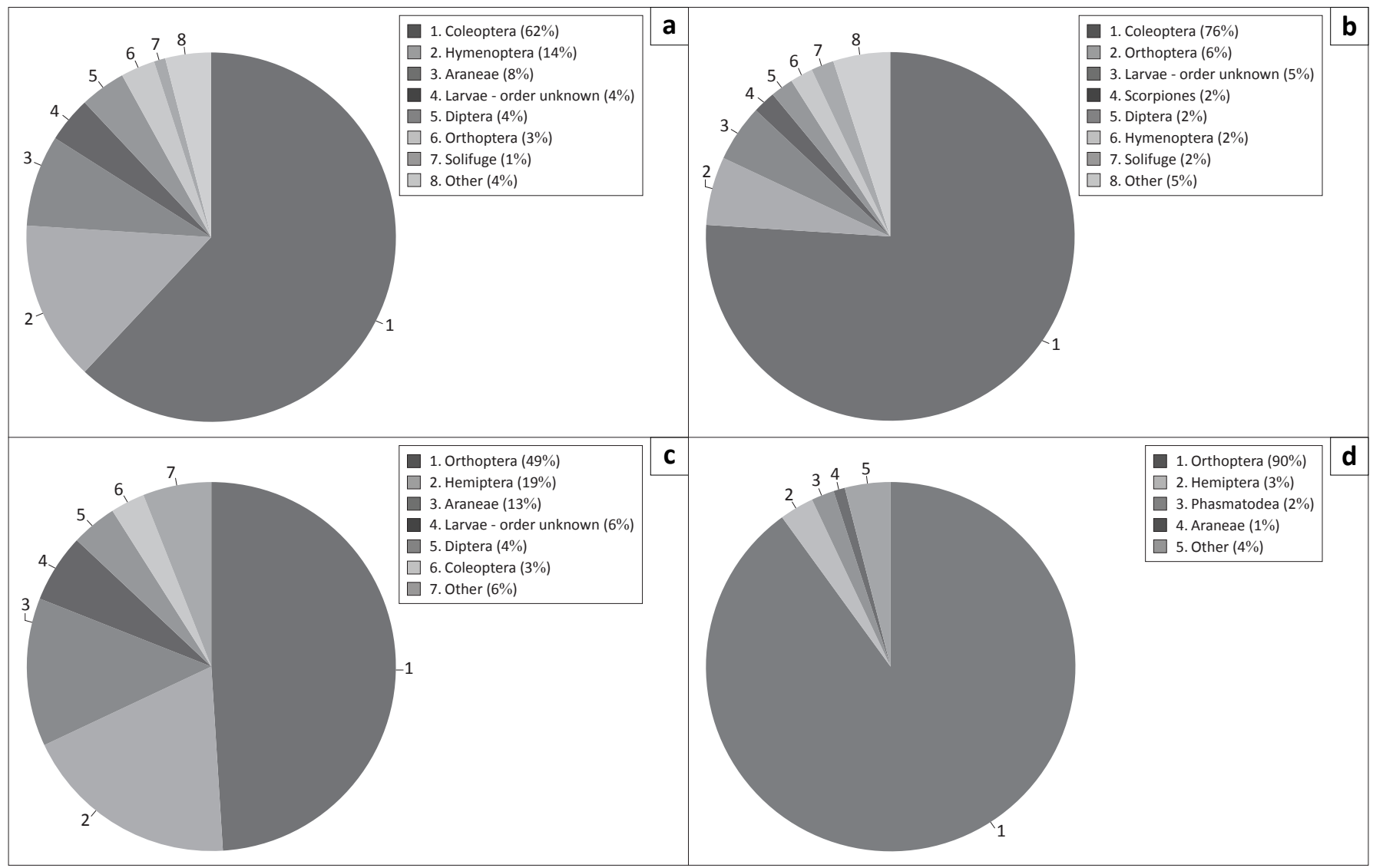

FIGURE 3: Comparison of the number and volume (determined using the volumetric water displacement method) of invertebrate orders captured by pitfall and sweep net sampling at four sites and expressed as a percentage according to, (a) numbers of invertebrates from pitfall traps categorised per order, (b) volume of invertebrates from pitfall traps categorised per order, (c) numbers of invertebrates from sweep nets categorised per order and (d) volume of invertebrates from sweep nets categorised per order. 


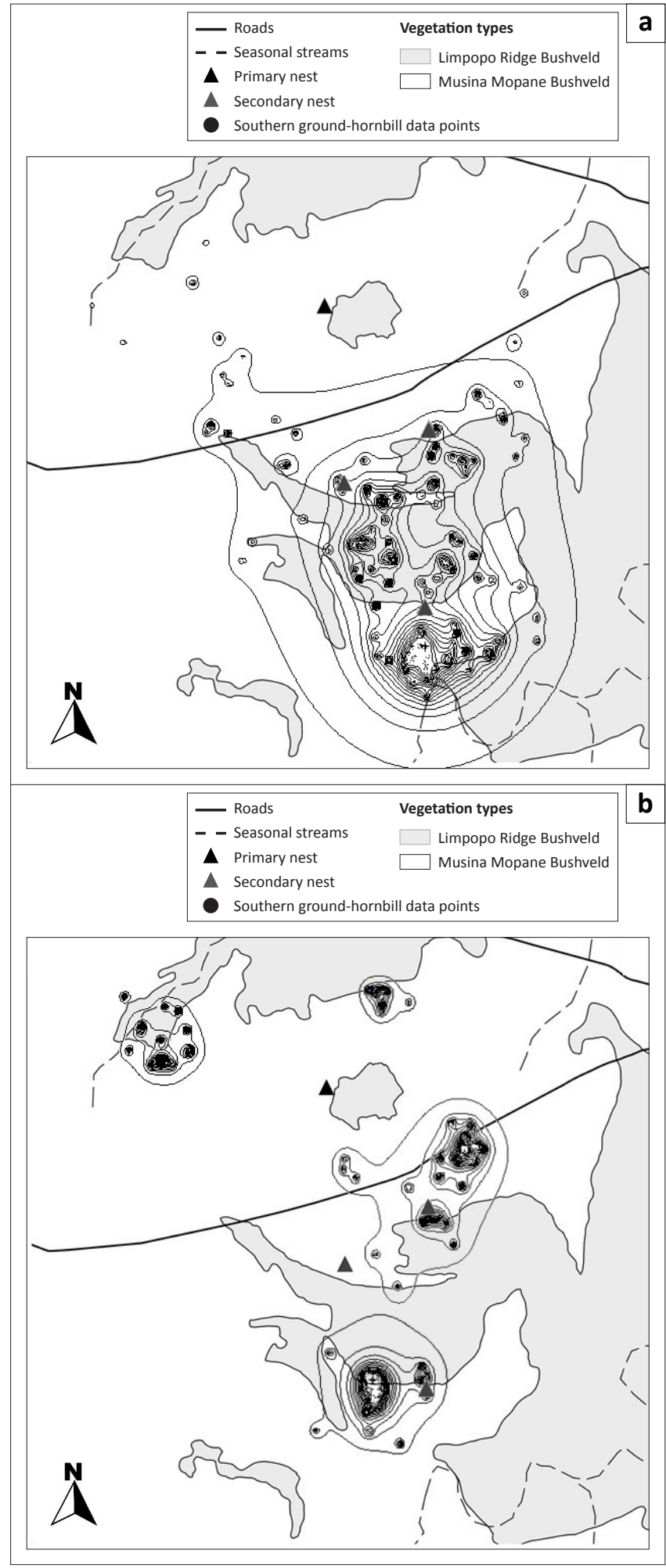

FIGURE 4: The (a) summer and (b) winter seasonal kernel home ranges of a Southern ground-hornbill group during the study period in relation to environmental features. Contour lines indicate kernel mean analyses using $95 \%$ fixes at $5 \%$ intervals.

\section{Discussion}

\section{Seasonal abundance of invertebrates}

This study reveals positive correlations between insect abundance and temperature and rainfall across seasons. This is similar to studies in other areas where wet and dry seasons alternate and insect abundance is influenced by temperature and rainfall (Da Silva, Frizzas \& De Oliveira 2011; Poulin, Gaetan \& McNeil 1992). In these variable environments, the seasonal abundance of invertebrates is related to the presence of food, which for herbivorous insects would be the flush of new leaves and grass brought about by the wet season, in turn influencing the abundance of predatory invertebrates (Wolda 1979). The Limpopo Valley experiences a distinct rainy season from November to March with grass growth immediately responding to the onset of rains, thus stimulating invertebrate activity and abundance. An extreme case of this response is the large scale and unpredictable outbreaks of the mopani worm (Lepidoptera: Imbrasia belins) which is known to occur in arid habitats dominated by C. mopane (Oberprieler 1986). Such an outbreak occurred within the SGH territory during the study but unfortunately the dramatic increase of invertebrate biomass was not reflected in our results because the outbreak did not occur in the invertebrate sampling site. However, the spectacular influence rainfall plays in this ecosystem is reflected by the sudden rainfall-induced emergence of a species of monster tiger beetle (Coleoptera: Manticora sp.) resulting in the volume of insects caught in pitfalls increasing six-fold in November, the third highest volume of insects caught for any particular month over the study period.

If future similar studies are undertaken, it is recommended that a more direct method of sampling mopani worms and other invertebrates is employed.

\section{Seasonal home range size and habitat utilisation}

Seasonal variations in home range size and the seasonal movements of the group are closely related to fluctuations in the surface abundance and availability of prey. The winter home range coincides with the period of lowest invertebrate abundance, is around $60 \%$ smaller than the summer home range and includes areas of core usage with large tracts of habitat where the group was not recorded. At the onset of summer in 2008, a sporadic and isolated thundershower occurred on the northern edge of the groups territory and the group immediately responded by moving to this area most likely in anticipation of the emergence of mopani moths and other invertebrates. Mopani moths and mopani worms are an important food resource for birds in this harsh environment, as shown by Gaston, Chown and Styles (1997) who found SGH feeding on mopani worms only during the fifth instar stage. Indeed, the group was again found concentrating in this area during March 2009 whilst the outbreak of mopani worms (N. Theron, pers. obs.) were in the fourth and fifth instar stage. Although observations of the study group could not be made, it is likely that the group was feeding on the profusion of mopani worms found throughout this area.

Winter foraging was characterised by bouts of foraging focused within very specific locations over a number of days, with sudden, deliberate long distance movements (of up to $20 \mathrm{~km}$ ) to other parts of the territory where localised foraging would again occur. These forays seemed to be purposeful rather than occurring in a random fashion and were likely 
undertaken to test other feeding areas known to the group before then returning to more productive foraging areas.

During the last few months of winter (July-September), shortly prior to the first rains in both 2008 and 2009, invertebrate numbers and grass cover were at their lowest. During this time, the movement of the group was restricted at times to less than $500 \mathrm{~m}$ per day, which, in 2008, was a camp with a high density of ungulates. Kemp et al. (1989) also recorded similar behaviour in the KNP, with SGH most often observed during the drier winter months in areas associated with a high density of ungulates and resultant invertebrate prey resources found in the dung of invertebrates. Furthermore, in the KNP, Kemp and Kemp (1980) noted that during winter SGH foraging behaviour changes and the group will switch from foraging behaviour that focuses on invertebrates above the ground to strategies involving turning over dung, logs and other items as well as subterranean digging for invertebrates - even up to depths of up to $40 \mathrm{~cm}$ (Kemp \& Kemp 1978). The ability of SGH to adapt and access invertebrates during winter is a key survival strategy in this harsh unpredictable habitat. It is interesting to note that species such as Secretary birds (Sagittarius serpentarius) and Kori Bustards (Ardeotis kori), which have similar feeding and habitat requirements to SGH but cannot access subterranean prey, are uncommon in the area. The survival and fitness of a long-lived K-selected, territorial species such as the SGH would be dependent on the ability of the alpha pair to react to, locate and access available food resources particularly during the drier winter months when food is the most limited.

\section{Southern ground-hornbill territory size}

The Limpopo Valley occurs at the south-western extent of the range of SGH and is a semi-arid environment. Semi-arid environments are generally less productive because the scarcity of rainfall affects the production of vegetation (Guttal \& Jayaprakash 2007). As such, the area may be considered marginal for $\mathrm{SGH}$ in terms of their habitat requirements, where SGH are recorded to prefer savanna habitats and being absent from largely treeless arid regions such as the Kalahari (Kemp 2005). The territory size of this group of SGH is almost double the size observed in the KNP (Kemp \& Kemp 1980) and KwaZulu-Natal (Knight 1990) and 10 times the size reported in the Mana Pools region of Zimbabwe (Kemp 2005) and the Masai Mara Reserve in Kenya (N. Theron, pers. obs.) which was calculated according to the density of groups. This corresponds with many studies that show a documented significant negative relationship between food abundance and territory size (Adams 2001). The relatively drier rainfall patterns found in South Africa in comparison to other parts of Africa provides an explanation for the extreme variations found in SGH territory size across the species range.

Many studies have shown that the abundance of food and the costs of expelling intruders are important determinants of territory size (Adams 2001). In this study, the effects of density and pressure from other groups are not expected to be an important factor because of the low density of SGH groups in the Limpopo Valley (Theron et al. 2013). Therefore, in the absence of density-dependant factors and with the observed sensitive interaction between rainfall, vegetation growth and invertebrate abundance, a large territory would in effect act as an insurance buffer increasing the chance that sporadic rainfall events occur in a group's territory. In addition, large territories are required to provide sufficient food resources in a nutrient-poor environment. It is likely therefore, that in the Limpopo Valley food availability is the primary factor determining territory size.

\section{Southern ground-hornbill nesting requirements}

Although nests are not a limiting factor for the SGH group studied, all seven known nests utilised by groups in the Limpopo Valley are found in A. digitata trees and there seems to be a pattern with SGH distribution related to the presence of large $A$. digitata trees (N. Theron, pers. obs.). This observation, however, needs to be verified by future ongoing monitoring of groups in the Limpopo Valley. In this semi-arid landscape, with few rivers, the conditions for the growth of suitably large trees containing nest holes is severely restricted, with $A$. digitata being the only common tree, not restricted to water courses, that can reach large enough dimensions for SGH nesting requirements. It is therefore plausible that the lack of $A$. digitata trees and the possible nesting cavities these trees may contain is the primary reason for the absence of SGHs in certain parts of the Limpopo Valley. In the future, the provision of artificial nests in these areas may prove an effective management intervention to encourage new groups to re-colonise these areas.

\section{Conclusion}

Owing to the sensitive nature of the Musina Mopane Bushveld and Limpopo Ridge Bushveld vegetation types and the unpredictable availability of food resources, a relatively large area (200 $\mathrm{km}^{2}$ per group) needs to be secured in order to support a viable population of SGH. This is especially relevant when considering that the only statutorily conserved portion of the study site falls within the Mapangubwe National Park. Little of these vegetation types have been transformed (Mucina \& Rutherford 2006), although mining is a looming threat and this highlights the important role private landowners need to play in maintaining the ecological integrity of vast tracts of this area and the conservation of SGH habitat in South Africa. Moreover, long-term ecological monitoring of this population of SGH is further required to fully understand the home range and habitat requirements within the Limpopo Valley. Of special interest is the competitive influence other groups may have as they re-colonise the area and the adjustment of territory size as population densities increase.

\section{Acknowledgements}

We are grateful to the farmers and landowners of the Limpopo Valley who granted us access to their farms, particularly the staff and management of Stokes Safaris. We would like to acknowledge financial and equipment support from the Tshwane University of Technology, the Mabula Ground 
Hornbill Research and Conservation Project, the University of the Free State and the National Research Foundation. We are also grateful to the South African Weather Service for providing climate data. Finally, we acknowledge the helpful inputs of three anonymous reviewers.

\section{Competing interests}

The authors declare that they have no financial or personal relationships that may have inappropriately influenced them in writing this article.

\section{Authors' contributions}

N.T. (University of the Free State) was responsible for project design, field work and data collection, data analyses and preparation of the manuscript. R.J. (Tshwane University of Technology) was the project leader and responsible for project design, statistical and home-range analyses and preparation of the manuscript. P.G. (University of the Free State) contributed towards project funding, project design and preparation of the manuscript. A.K. (University of the Free State) contributed towards project funding, project design and preparation of the manuscript.

\section{References}

Adams, E.S., 2001, 'Approaches to the study of territory size and shape', Annual Review of Ecology and Systematics 32, 277-303. http://dx.doi.org/10.1146/annurev. ecolsys.32.081501.114034

BirdLife International, 2010, The BirdLife data zone, viewed 01 March 2010, from http:// www.birdlife.org/datazone/species

Block, W.M. \& Brennan, L.A., 1993, 'The habitat concept in ornithology: Theory and applications', Current Ornithology 11, 35-91. http://dx.doi.org/10.1007/978-14757-9912-5_2

Da Silva, N.A.P., Frizzaz, M.R. \& De Oliveira, C.M., 2011, 'Seasonality in insect abundance in the "Cerrado" of Goiás State, Brazil', Revista Brasileira de Entomologia 55(1) 79-87. http://dx.doi.org/10.1590/S0085-56262011000100013

Gaston, K.J., Chown, S.L. \& Styles, C.V., 1997, 'Changing size and changing enemies: The case of the mopane worm', Acta Oecologica 18(1), 21-26. http://dx.doi. org/10.1016/S1146-609X(97)80077-X

Guttal, V. \& Jayaprakash, C., 2007, 'Self-organization and productivity in semi-arid ecosystems: Implications of seasonality in rainfall', Journal of Theoretical Biology 248, 490-500. http://dx.doi.org/10.1016/j.jtbi.2007.05.020, PMid:17645895

Hall, L.S., Krausman, P.R. \& Morrison, M.L., 1997, 'The habitat concept and a plea for standard terminology', Wildlife Society Bulletin 25(1), 173-182.

Jansen, R. \& Crowe, T.M., 2006, 'Food preferences of Swainson's Spurfowl, Pternistis swainsonii, in a diverse agricultural landscape', South African Journal of Wildlife Research 36(2), 113-121.
Jordaan, J.J., Wessels, D.C.J., Dannhauser, C.S. \& Rootman, G.T., 2004, 'Secondary succession in the Mopani Veld of the Limpopo Valley, South Africa', African Journal of Range and Forage Science 21(3), 205-210. http://dx.doi.org/10.2989/10220110409485853

Kemp, A.C., 1976, 'Factors affecting the onset of breeding in African hornbills', Proceedings of the 16th International Ornithological Congress, Canberra, Australia, August $12-17,1974$, pp. 248-257.

Kemp, A.C., 1988, 'The behavioural ecology of the Southern Ground Hornbill: Are competitive offspring at a premium?', Proceedings of the International $100 \mathrm{DO}-\mathrm{G}$ meeting, current topics in avian biology, Bonn, Germany, 1988, pp. 267-271.

Kemp, A.C., 1995, The Hornbills, Bucerotiformes, Oxford University Press, Oxford.

Kemp, A.C., 2000, 'Southern ground hornbill', in K.N. Barnes (ed.), The Eskom red dato book of birds of South Africa, Lesotho and Swaziland, pp. 117-119, BirdLife South Africa, Johannesburg.

Kemp, A.C., 2005, 'Ground hornbills', in P.A.R. Hockey, W.A.J. Dean \& P.G. Ryan (eds.), Roberts birds of southern Africa, 7th edn., pp. 158-159, John Voelcker Bird Book Fund, Cape Town.

Kemp, A.C. \& Kemp, M.I., 1980, 'The biology of the Southern ground hornbill Bucorvus leadbeateri (Vigors) (Aves: Bucerotidae)', Annals of the Transvaal Museum 32(4), 65-100.

Kemp, A.C. \& Kemp, M.I., 1991, 'Timing of egg laying by Southern Ground Hornbills Bucorvus leadbeateri in the central Kruger National Park, South Africa', Ostrich 62, 80-82.

Kemp, A.C., Joubert, S.C.J. \& Kemp, M.I., 1989, 'Distribution of Southern ground hornbills in the Kruger National Park in relation to some environmental features', Southern African Journal of Wildlife Research 19(3), 93-98.

Kemp, M.I. \& Kemp, A.C., 1978, 'Bucorvus and Sagittarius: Two modes of terrestria predation', in A.C. Kemp (ed.), Proceedings of the Symposium on African Predatory predation', in A.C. Kemp (ed.), Proceedings of the Symposium
Birds, Northern Transvaal Ornithological Society, Pretoria.

Knight, G.M., 1990, 'Status, distribution and foraging ecology of the Southern Ground Hornbill (Bucorvus cafer) in Natal', Unpublished MSc Thesis, Department of Zoology and Entomology, University of Natal, Durban.

Mucina, L. \& Rutherford, M.C., 2006, 'The vegetation of South Africa, Lesotho and Swaziland', Strelitzia 19, South African Botanical Institute, Pretoria.

Oberprieler, R., 1986, 'Pinus radiata. Don: A new foodplant record for Imbrasia (Gonimbrasia) belina (Westwood) (Lepidoptera: Saturniidae)', Journal of the Entomological Society of Southern Africa 49, 168-170.

Perner, J. \& Schueler, S., 2004, 'Estimating the density of ground-dwelling arthropods with pitfall traps using a nested-cross array', Journal of Animal Ecology 73, 469-477. $\mathrm{http}: / / \mathrm{dx}$.doi.org/10.1111/j.0021-8790.2004.00821.x

Poulin, B., Gaetan, L. \& McNeil, R., 1992, 'Tropical avian phenology in relation to abundance and exploitation of food resources', Ecology 73(6), 2295-2309. http:// dx.doi.org/10.2307/1941476

Seaman, A.D. \& Powell, R.A., 1996, 'An evaluation of the accuracy of kernel density estimators for home range analysis', Ecology 77(7), 2075-2085. http://dx.doi. org/10.2307/2265701

South, A.B., Kenward, R.E. \& Walls, S.S., 2008, Ranges 7: For the analysis of tracking and location data, Online Manual, Anatrack Ltd., Wareham.

Standen, V., 2000, 'The adequacy of collecting techniques for estimating species richness of grassland invertebrates', Journal of Applied Ecology 37(5), 884-893. http://dx.doi. org/10.1046/j.1365-2664.2000.00532.x

STATISTICA version 9, 2009, computer software, Statsoft Inc., Tulsa.

Theron, N.T., Dalton, D., Grobler, J.P., Jansen, R. \& Kotze, A., 2013, 'Molecular insights on the re-colonization of the Limpopo Valley, South Africa, by Southern GroundHornbills', Journal of Ornithology 154(3), 727-737. http://dx.doi.org/10.1007/ s10336-013-0937-4

Vernon, C.J., 1984, 'The Ground hornbill at the southern extremity of its range', Ostrich 57, 16-24. http://dx.doi.org/10.1080/00306525.1986.9633633

Wolda, H., 1979, 'Seasonality parameters for insect populations', Researches on Population Ecology 20(2), 247-256. http://dx.doi.org/10.1007/BF02512630 